\title{
A Hedonic Analysis of the Impact of Tree Shade on Summertime Residential Energy Consumption
}

\author{
Ram Pandit and David N. Laband
}

\begin{abstract}
Trees cast shade on homes and buildings, lowering the inside temperatures and thus reducing the demand for power to cool these buildings during hot times of the year. Drawing from a large sample of residences in Auburn, Alabama, U.S., a statistical model was developed to produce specific estimates of the electricity savings generated by shade-producing trees in a suburban environment. This empirical model links residential energy consumption to hedonic characteristics of the structures, characteristics/behaviors of the occupants, and the extent and density of shade cast on the structures at different times of the day.

Key Words: Electricity Usage; Economic Value; Shade Density; Shading Time; Tree Shade.
\end{abstract}

Trees cast shade on homes and buildings, lowering the inside temperatures and thus reducing the demand for power to cool these buildings during hotter times of the year. The savings may be sizable because electricity usage for cooling houses in summer months is costly for those who live in hot climates. Particularly in the Sun Belt area of the U.S. (the southern states stretching from South Carolina to Florida, along the Gulf of Mexico, across to southern California), the energy used for air conditioning makes up a large fraction of the peak electrical utility loads during the warmest period of summer (Rudie and Dewers 1984). As the cost of electricity has increased in recent years, the amount and cost of electricity usage for cooling homes has become a significant expense to residents and industries in these areas.

With respect to the value of using tree shade to help cool dwellings, with the exception of Rudie and Dewers (1984), there is little to no scientific guidance for hard estimates using real data from a large number of sample households. The cooling effect of trees is most important during the period of maximum temperature and solar radiation (Parker 1983). Therefore, shade trees are considered as a possible demand-side management resource to provide cost-effective energy saving benefits to home and business owners (McPherson and Simpson 1995). In addition, the extent, timing, and density of shade cast by trees surely are important factors in reducing the demand for power. However, the available scientific literature provides very limited empirical information on the impact of the extent, density, duration, and/or timing of tree shade on energy used to cool houses during hot summer months.

Most of the available analyses of empirical link between tree shade and residential energy usage are based on simulation exercises. For example, the simulation results of Simpson and McPherson (1996) indicated that two trees shading the westfacing exposure of a house and one tree shading the east-facing exposure reduced annual energy use for cooling by $10 \%$ to $50 \%$ and peak electrical use up to $23 \%$. Huang et al. (1987) conducted a simulation study of the potential role of vegetation in reduc- ing summer cooling energy in residential houses across 4 U.S. cities. Their results suggested that an additional $25 \%$ increase in tree cover would reduce annual cooling energy use by $40 \%$, $25 \%$, and $25 \%$ for an average house in Sacramento, Phoenix, and Lake Charles, respectively. However, the fourth city, Los Angeles, had minimal calculated savings. Similarly, another simulation study by McPherson et al. (1997) in Chicago indicated that three $7.6 \mathrm{~m}$ tall trees around a well-insulated new house would reduce annual heating and cooling costs by $8 \%$ as compared to otherwise identical houses without trees. However, conclusions drawn from these tightly controlled simulation exercises may not accurately reflect the savings realized by consumers, who lead lives that are considerably more complicated, in terms of energy consumption, than simulation exercises admit.

There are a few empirical studies of shade trees and residential energy consumption based on real-world data, but the usefulness of the findings generated by these studies (Akbari et al. 1992; Akbari et al. 1997; Carver et al. 2004) is limited due to small samples, except Rudie and Dewers (1984), or the absence of rigorous controls for confounding effects (Clark and Berry 1995; Laverne and Lewis 1996). For example, Akbari et al. (1997) analyzed the impact of shade trees on peak power and cooling energy use in two houses in Sacramento, CA and found a 30\% reduction in energy use and 0.6 to 0.8 kilowatt peak demand savings due to shade trees.

Rudie and Dewers (1984), an exception to the small sample size limitation, examined the impact of shade cast in different coverage categories on energy consumption by 113 residents in College Station, TX. They evaluated tree shade on roofs for three years (1977-1979) from June to September, using measured tree height to estimate the amount of shade cast based on hourly solar position on the twenty-first day of each month. They developed a shade score for each home ranging from 1 to 4 based on the shaded roof perimeter and wall space, and classified each homes into one of four shade categories [category 1 with $4.27 \mathrm{~m}$ or greater depth of shade and category four homes 
with no shade/trees] to analyze energy savings as a result of tree shade. Their findings for different shade categories indicated that the amount of shade, roof color, and wall color were significant determinants of residential energy consumption.

However, Jensen et al. (2003) found a different impact of tree shade on residential energy consumption using a Leaf Area Index (LAI) measure derived from remote sensing data. In their study, Jensen's team randomly selected 118 LAI points to represent Terre Haute, IN and regressed the residential energy consumption against LAI values. The regression estimation produced statistically insignificant results, contradicting the strong and significant role of shade trees on residential energy consumption revealed by other studies.

Drawing from a sample of 160 residences in Auburn, Alabama, a statistical model was developed to produce specific estimates of the electricity savings generated by shade-producing trees in a suburban environment. This empirical model links residential energy consumption to hedonic characteristics of the structures, characteristics/behaviors of the occupants, and the extent and density of shade cast on the structures at different times of the day.

\section{METHODOLOGY}

\section{Study Area}

The study authors selected the city of Auburn, Alabama, located at $32^{\circ} 37^{\prime} \mathrm{N}$ latitude and $85^{\circ} 29^{\prime} \mathrm{W}$ longitude, to conduct this study for both climatic and demographic reasons. The climatic conditions of Auburn are characteristic of the Gulf Coast region generally, where winters are cool but short, and summers are long, hot, and humid. Lechner (1991) concluded that $12 \%$ of the days each year are regarded as 'comfortable,' $36 \%$ of the days are regarded as 'too cold,' and 52\% of the days are regarded as 'too hot.' The average annual heating and cooling degree-days for this region are 1,490 and 2,686, respectively (Lechner 1991). Consequently, in Auburn, cooling energy needed during the summer is far greater than heating energy needed during the winter.

The changing demography of Auburn coupled with its fastpaced economic growth in recent years also fits the study's needs in two respects. First, the findings may be useful to home builders in terms of integrating shade trees in the planning process for new residential construction in order to reduce the energy requirement for new homes, particularly during summer months. In January 2008, Forbes Magazine (2008) named the Auburn-Opelika Metropolitan Statistical Area (MSA) the sixth fastest-growing MSA in the U.S. for small metros and projected Auburn's 2007 population $(54,348)$ would grow by more than $17 \%$ and its current Gross Metropolitan Product (GMP), the market value of all final goods and services produced within a metropolitan area, would increase by more than $24 \%$ by the year 2012 . Second, the mix of recently developed neighborhoods and older neighborhoods within the city of Auburn provides the range of shade conditions needed for this study-houses with little-to-no tree canopy to houses with substantial tree canopy. Camden Ridge, New Grove Hill, Ogletree Village, and North Donahue are the recently developed neighborhoods in the city, which either have no trees or have relatively few and small trees per lot that cast little, if any, shade on residences. In contrast, Willow Creek, Twin Creeks, Sugar Creek, Moore's Mill, Old Grove Hill, and Cary Woods are older neighborhoods, which have many and large trees that cast substantial shade on residences. The study included houses from all of these neighborhoods, to ensure that a wide range of tree shade conditions are represented in the sample. Even within each neighborhood, there is substantial variation between residences with respect to the extent and density of tree-cast shade.

\section{Data Collection}

The study authors used a hedonic model as the analytical framework. Specifically they employed multivariate regression estimation techniques to estimate the impact of shade conditions on monthly electricity consumption, controlling for a variety of other factors that also affect monthly electricity usage such as: size of family, gender and age distribution of occupants, loads of laundry per week, dwelling characteristics (e.g., age, square footage, number of floors), and energy sources for cooking and water heating.

The information needed came from two sources: 1) the residents themselves (in response to a survey questionnaire and through submission of monthly electric bills), and 2) direct observation of shade conditions on the properties in the sample.

\section{Survey Questionnaire}

A two step approach was adopted in identifying sample participants. First, an invitation letter for participation and a questionnaire was personally delivered to the door knobs or mailboxes of semi-randomly selected potential homeowners. The selection of neighborhoods was deliberate, in order to reflect substantial variation in tree shade conditions. Within each neighborhood, however, distribution of invitations was random, whereas every other home received an invitation. The invitation letters explained the nature and scope of the study and provided relevant contact information for the respondent to use to indicate their willingness to participate.

Second, based on the email or telephone contact from the participants, who indicated their willingness to participate in the study, a meeting with each of the potential participants was scheduled at their convenience to: 1) indicate the range of information required from the participant, including information from their monthly electricity bill, 2) have them approve access by the researchers to their property for shade monitoring every month, 3) address any questions/concerns they had about the study, and finally, 4) collect the completed questionnaire that contained information on occupants (number, age, gender), structural characteristics of the house (e.g., age, living area, story, swim pool, outside wall color, and materials), and utility types for heating/cooling their house (e.g., electricity, natural gas, others).

The final sample of 160 homeowners located in 11 Auburn City neighborhoods represented $8.3 \%$ of the homeowners initially contacted. This sample size was sufficient to reflect the complete range of shade conditions (both extent and density) on properties, as well as the other explanatory variables in the model and to provide a statistically valid sample size for a regression estimation.

\section{Monthly Field Visit for Shade Characteristics}

Each sample house was visited each month to record the extent and density of shade cast on each house by nearby tree canopy. Information on the extent and density of shade on each house was collected at three different times in a sunny day-late a.m. (9:00-11:00 a.m.), early p.m. (noon-2:00 p.m.), and late p.m. (3:00-5:00 p.m.) - around the middle of each month throughout the year to explore the timing effect of shade on power consumption. An ocular observation was used to estimate both the extent 
and density of tree shade at each property. The extent of treecast shade on the roof of each house was recorded on a decile percentage scale $(0 \%, 1$ to $10=10 \%, 11$ to $20=20 \% \ldots, 91$ to $100=100 \%)$. Similarly, shade density type was recorded in one of four density classes: heavy, moderate, light, and no shade. Heavy shade density refers to shade characterized by few-to-no patches of sunlight, light shade density refers to shade that allows most of the sunlight shine onto the structure, and moderate shade density is characterized by roughly equal amounts of sunlight and shade upon the dwelling. The same researcher monitored the extent and density of shade cast on each house every time to ensure consistency and uniformity with respect to the data.

\section{Communication for Monthly Electricity Usage}

Information on monthly electricity usage from each participating house was collected through e-mail and/or phone communication. An e-mail or telephone reminder was sent to each participant every month coinciding with their power bill arrival, requesting information on monthly power consumption.

\section{Data Description}

\section{Questionnaire Survey Data}

Data on characteristics of the dwelling and the occupants were collected at the onset of the study using the survey questionnaire. The building characteristics included: age of house (years), living space (square feet), number of stories/levels, cooling system (central air or window unit), cooking/heating and hot water systems (electricity, natural gas, or others), exterior construction materials, presence or absence of swimming pool, and presence of an additional freezer. The occupant(s) characteristics included: total number of family members by age and gender, and average quantity of laundry run per week. In addition, information on the daytime and nighttime inside house temperature maintained by the residents both in summer and winter months was collected. In conjunction with information about exterior temperatures, this provided a measure of the intensity of the cooling (heating) regime at each residence across different seasons and months.

\section{Weather Data}

Assuming homogeneous outside weather conditions across sample households, the study authors collected daily temperature and humidity data for the city of Auburn from the National Weather Service reporting station located at the Auburn airport. Daily maximum and minimum readings for temperature and humidity were collected for 12 months and were used to compute daily averages. Then, periodic averages for temperature and humidity were computed based on electricity service periods (i.e., the period between start and end dates of electric services mentioned in each utility bill), for each participating household. Service periods vary across the neighborhoods, even within the neighborhood if it is a large one, creating different start and end dates of the billing cycles among neighborhoods. For example, a house in the Twin Creeks neighborhood had a service period running from August 7 to September 8, whereas a house in the Willow Creek neighborhood had a service period that ran from August 12 to September 12. These weather-related variables serve as the basis to compare electricity consumption across sample households with varying service periods.
The intensity of artificial cooling (in summer) depends on the difference between inside and outside temperature of the house during the day or at night. The daytime, outside temperature is relevant for summer months when cooling the house is done mostly during the day (when temperatures peak). The total amount of electricity consumed for cooling depends on the magnitude of the difference between outside and inside temperatures (tempdiff), as this difference reflects the intensity of the cooling effort needed for a house. The higher the positive temperature difference during summer months, the greater the amount of electricity consumed to cool the house and vice-versa.

\section{ElectricityData}

Starting with August 2007, monthly electricity usage data were collected from each participating household for a year. Specifically, information on dates of current service, number of days in service period, and the amount of electricity consumed during the specified period. Even though electricity usage data for 12 months (August 2007 - August 2008) were collected, the study authors were able to develop the power usage data for the 24-month period (August 2006 - August 2008). In each bill, the power companies report three sets of power usage information to the customers: the current month, the previous month, and previous year by number of days in the billing period and kilowatt hours (kWh) of consumption. Using this information a dependent variable (power consumption per day) for each household for both the current period and previous-year service periods was generated.

\section{Tree Shade Data}

Monthly data on the extent and density of tree-cast shade was recorded through field visits. The extent of shade estimated in decile percentages three times a day was averaged to obtain a mean percentage of shade on each house. Similarly, a single measure of shade density was constructed from the three density observations taken at different times of the day. It was derived using a weighted scheme reflecting the extent and density of shade. For example, if a house received $15 \%$ heavy shade in the late morning, 5\% moderate shade in early afternoon, and $55 \%$ heavy shade in the late afternoon, then the mean shade extent for this house was assigned at $25 \%$ and shade density assigned was heavy. The shade density type was specified based on the frequency and extent of its periodic occurrence.

For this study it was assumed there was no variation on extent and density of tree-cast shade on each home between current year and previous year. This assumption was cross-checked with participants by asking them to report any landscaping changes in their yard/lot. Participant responses indicated that this assumption was realistic, which, in turn, allowed the study authors to double the sample size by using the previous-year electricity usage information with the tree shade conditions measured during the current year.

Several attributes of the residences in the sample and the occupants of those residences are invariant across the entire year of the study period. Sample statistics for these variables are reported in Table 1a. Sample statistics for time-dependent variables are reported in Table 1b. Sample statistics for categorical variables by utility or structural types are reported in Table 1c.

Figure 1 shows average daily electricity consumption over the period May-September. It will come as no surprise that electricity consumption rises throughout June and 
July, peaks in August, and then starts to decline. This pattern is perfectly consistent with the trend in the intensity of desired cooling (measured in two different ways by the high and

Table 1a. Sample statistics for time-invariant attributes

\begin{tabular}{lcccc}
\hline Attributes & Mean & Std. Dev. & Min. & Max. \\
\hline Living area $\left(\mathrm{ft}^{2}\right)$ & $2,700.15$ & 854.93 & 1,170 & 6,100 \\
$\quad\left(\mathrm{~m}^{2}\right)$ & $(251.18)$ & $(79.53)$ & $(108.84)$ & $(567.45)$ \\
Number of floors & 1.52 & 0.51 & 1 & 3 \\
Family size & 2.5 & 1.13 & 1 & 7 \\
Family size by gender & & & & \\
$\quad$ Male & 1.25 & 0.87 & 0 & 5 \\
$\quad$ Female & 1.25 & 0.60 & 0 & 3 \\
Family size by age group & & & & \\
$\quad \leq 12$ years & 0.45 & 0.90 & 0 & 5 \\
$\quad$ 13 to 24 years & 0.19 & 0.50 & 0 & 3 \\
$\quad 25$ to 60 years & 1.25 & 0.88 & 0 & 3 \\
$\quad>60$ years & 0.62 & 0.85 & 0 & 2 \\
$\quad 14.49$ & 12.36 & 1 & 57 \\
Age of the house (Yr) & 7.52 & 5.85 & 1 & 32 \\
Age of air conditioner (Yr) & 7.94 & 5.95 & 1 & 32 \\
Age of heating unit (Yr) & 7.21 & 5.20 & 1 & 28 \\
Age of water heater (Yr) & 5.53 & 3.08 & 1 & 21 \\
No. of laundry/week & & &
\end{tabular}

mean temperature difference lines). These lines reflect the difference between actual outside temperature and each home owner's self-identified thermostat setting in the summertime.

Table 1c. Sample statistics for categorical variables by utility or structural types.

\begin{tabular}{llc}
\hline Variables & Utility / structural type & \# of sample households \\
\hline Air conditioner & Central air electric & 156 \\
& Central air electric & 4 \\
with window unit & \\
Heating & Partially or fully electric & 107 \\
& Others (natural gas, & 53 \\
Cooking & propane, etc.) & \\
& Partially or fully electric & 129 \\
Water heater & Natural gas & 31 \\
& Partially or fully electric & 84 \\
House floors & Natural gas & 76 \\
& Single & 77 \\
Swimming pool & Multiple & 83 \\
& Yes & 12 \\
Second freezer & No & 148 \\
& Yes & 83 \\
& No & 77 \\
\hline
\end{tabular}

Table 1b. Sample statistics for time-variant attributes.

\begin{tabular}{|c|c|c|c|c|}
\hline Attributes & Mean & Std. Dev. & Min. & Max. \\
\hline $\mathrm{kWh} /$ day & 58.50 & 27.59 & 0.02 & 192.97 \\
\hline Daytime inside temp. ${ }^{\circ} \mathrm{F}\left({ }^{\circ} \mathrm{C}\right)$ & $76.35(24.64)$ & 2.74 & $70.00(21.11)$ & $85.00(29.44)$ \\
\hline Nighttime inside temp. ${ }^{\circ} \mathrm{F}\left({ }^{\circ} \mathrm{C}\right)$ & $75.65(24.25)$ & 3.16 & $65.00(18.33)$ & $85.00(29.44)$ \\
\hline Outside high temp. ${ }^{\circ} \mathrm{F}\left({ }^{\circ} \mathrm{C}\right)$ & $88.00(31.11)$ & 5.27 & $73.53(23.07)$ & $95.61(35.34)$ \\
\hline Outside mean temp. ${ }^{\circ} \mathrm{F}\left({ }^{\circ} \mathrm{C}\right)$ & $77.84(25.47)$ & 5.54 & $62.31(16.84)$ & $85.03(29.46)$ \\
\hline Outside min. temp. ${ }^{\circ} \mathrm{F}\left({ }^{\circ} \mathrm{C}\right)$ & $67.22(19.57)$ & 5.89 & $50.53(10.29)$ & $73.94(23.30)$ \\
\hline Average humidity $(\%)$ & 73.72 & 4.06 & 64.02 & 81.20 \\
\hline Daytime mean temp. diff. & 1.49 & 6.16 & -16.41 & 15.03 \\
\hline Nighttime mean temp. diff. & 2.19 & 6.35 & -18.45 & 18.79 \\
\hline $\begin{array}{c}\text { Percentage of house area } \\
\text { under tree shade }\end{array}$ & 17.46 & 19.44 & 0.00 & 88.00 \\
\hline $\begin{array}{l}\text { Late a.m. (9-11 a.m.) percent } \\
\text { house area under } \\
\text { tree shade }\end{array}$ & 20.93 & 25.30 & 0.00 & 100.00 \\
\hline $\begin{array}{c}\text { Early p.m. }(12-2 \text { p.m.) percent } \\
\text { house area under } \\
\text { tree shade }\end{array}$ & 10.23 & 14.93 & 0.00 & 90.00 \\
\hline
\end{tabular}

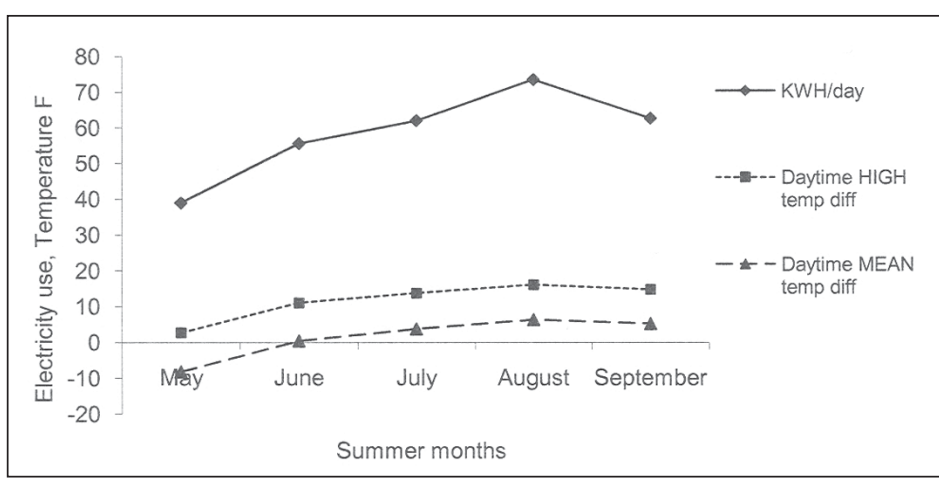

Figure 1. Summertime average daily electricity use and desired cooling. 


\section{MODEL AND ANALYSIS}

Equation 1 is a conceptual representation of the estimating model linking residential energy consumption to hedonic characteristics of the house, characteristics/behaviors of the occupants, climatic conditions of the neighborhood, and the extent and density of shade cast on the house at different times of the day.

[1] Daily Electricity Consumption $=\mathrm{f}$ (hedonic characteristics, occupant characteristics, climatic conditions, percent shade, shade density)

Empirical analysis covered the period from May 1-September 30 , which includes the months with a positive difference between mean outdoor temperature and desired indoor temperature. Equation 2 is the specific model estimated to identify the impact of tree shade and density on daily electricity consumption during the summer season, controlling for other relevant variables.

$$
\begin{aligned}
& \text { DEC }_{\mathrm{ijk}}=\alpha 0+\alpha 1 \text { Freezer }_{\mathrm{ij}}+\alpha 2 \text { Cook }_{\mathrm{ij}}+\alpha 3 \text { Air }_{\mathrm{ij}}+ \\
& \alpha 4 \text { Occupants }_{\mathrm{ij}}+\alpha 5 \text { HouseAge }_{\mathrm{ijj}}+\alpha 6 \text { Space }_{\mathrm{ij}}+ \\
& \alpha 7 \text { Laundry }_{\mathrm{ij}}+\alpha 8 \text { Floors }_{\mathrm{ij}}+\alpha 9 \text { Pool }_{\mathrm{ij}}+\alpha 10 \text { WaterHeat }_{\mathrm{ij}} \\
& +\alpha 11 \text { Tempdiff }_{\mathrm{ij}}+\alpha 12 \text { Humid }_{\mathrm{ij}}+\alpha 13 \text { PercentShade }_{\mathrm{ijk}} \\
& +\alpha 14 \text { ShadeDensity }_{\mathrm{ijk}}+\varepsilon_{\mathrm{ijk}}
\end{aligned}
$$

where,

DEC = daily electricity consumption (kilowatt hours) by an individual house in a given service period

Freezer $=$ whether the house has one or more additional freezer units

Cook = whether the household uses any amount of electricity for cooking

Air = whether the air conditioning system is window unit (1), or central-air (0)

Occupants $=$ number of family members in residence

HouseAge $=$ age of the house in years

Space = living area of the house in square feet

Laundry $=$ average number of laundry loads run per week in the house

Floors = whether the house has multiple floors

Pool = whether the house has a swimming pool

WaterHeat $=$ whether the house has one or more water heaters that use electricity

Tempdiff $=$ the average daytime outside temperature minus the daytime thermostat setting for a given service period

Humid = average relative humidity for a given service period

PercentShade $=$ the extent of the roof area covered by tree shade, in decile percentages

ShadeDensity = the intensity of tree shade cast on the dwelling, assigned one of four categories: no shade, light, moderate, or heavy

$\varepsilon_{\mathrm{ijk}} \quad=$ model error term, assumed to be normally distributed

$\mathrm{i}_{\mathrm{j}} \quad=$ sample households $(\mathrm{i}=1$ to 160$)$

$\mathrm{j} \quad=$ service period or electricity billing cycle for each $\mathrm{i}$ ( $\mathrm{j}=1$ to 5; e.g., May, June, July, August, and September)

$\mathrm{k} \quad=$ shade monitoring times in a day per month $(\mathrm{k}=1$ to 3 ; 1 for late a.m., 2 for early p.m., and 3 for late p.m.)

\section{RESULTS}

Table 2 reports Ordinary Least Squares regression results for Equation 2 , in which family size is treated first as a single variable, then with the number of males and females identified, and finally with categorical variables that control for the age distribution of family members. Taken together, the results reveal relationships that are consistent with expectations and are consistent across model specifications. The overall explanatory power of these relatively parsimonious models is quite high, with almost all explanatory variables having a statistically significant impact on daily electricity usage.

\begin{tabular}{|c|c|c|c|}
\hline Explanatory Variables & Model & Model 2 & Model 3 \\
\hline Intercept & $\begin{array}{r}-10.450 \\
(9.622)\end{array}$ & $\begin{array}{r}-12.520 \\
(9.608)\end{array}$ & $\begin{array}{l}-9.491 \\
(9.747)\end{array}$ \\
\hline Family size & $\begin{array}{r}3.390^{\mathrm{z}} \\
(0.474)\end{array}$ & & \\
\hline \# Females & & $\begin{array}{r}5.250^{\mathrm{z}} \\
(0.786)\end{array}$ & \\
\hline \# Males & & $\begin{array}{r}2.394^{z} \\
(0.607)\end{array}$ & \\
\hline 12 or under & & & $\begin{array}{r}4.014^{z} \\
(0.616)\end{array}$ \\
\hline $13-24$ & & & $\begin{array}{c}0.640 \\
(1.081)\end{array}$ \\
\hline $25-60$ & & & $\begin{array}{c}1.716 \\
(1.153)\end{array}$ \\
\hline Over 60 & & & $\begin{array}{c}0.847 \\
(1.196)\end{array}$ \\
\hline Living area & $\begin{array}{r}0.013^{z} \\
(0.001)\end{array}$ & $\begin{array}{r}0.013^{z} \\
(0.001)\end{array}$ & $\begin{array}{r}0.013^{z} \\
(0.001)\end{array}$ \\
\hline House age & $\begin{array}{r}0.103^{y} \\
(0.046)\end{array}$ & $\begin{array}{r}0.108^{y} \\
(0.046)\end{array}$ & $\begin{array}{r}0.145^{z} \\
(0.047)\end{array}$ \\
\hline \# floors & $\begin{array}{r}1.974^{x} \\
(1.066)\end{array}$ & $\begin{array}{r}2.231^{\mathrm{y}} \\
(1.063)\end{array}$ & $\begin{array}{r}2.099^{y} \\
(1.063)\end{array}$ \\
\hline Elec. Cooking & $\begin{array}{l}-1.172 \\
(1.285)\end{array}$ & $\begin{array}{l}-1.421 \\
(1.283)\end{array}$ & $\begin{array}{l}-1.025 \\
(1.299)\end{array}$ \\
\hline Elec. $\mathrm{H}_{2} \mathrm{O}$ heat & $\begin{array}{r}4.547^{2} \\
(0.979)\end{array}$ & $\begin{array}{r}4.569^{2} \\
(0.976)\end{array}$ & $\begin{array}{r}4.007^{z} \\
(0.999)\end{array}$ \\
\hline Window AC & $\begin{array}{c}4.115 \\
(2.675)\end{array}$ & $\begin{array}{r}4.375^{\mathrm{x}} \\
(2.660)\end{array}$ & $\begin{array}{r}5.437^{y} \\
(2.727)\end{array}$ \\
\hline Laundry loads/wk & $\begin{array}{r}1.076^{2} \\
(0.169)\end{array}$ & $\begin{array}{r}1.085^{2} \\
(0.168)\end{array}$ & $\begin{array}{r}1.142^{z} \\
(0.169)\end{array}$ \\
\hline Second Freezer & $\begin{array}{r}2.475^{z} \\
(0.959)\end{array}$ & $\begin{array}{r}2.807^{z} \\
(0.959)\end{array}$ & $\begin{array}{r}2.945^{z} \\
(0.980)\end{array}$ \\
\hline Swimming pool & $\begin{array}{r}21.010^{z} \\
(1.761)\end{array}$ & $\begin{array}{l}20.84^{z} \\
(1.757)\end{array}$ & $\begin{array}{r}21.179^{z} \\
(1.763)\end{array}$ \\
\hline Average humidity & $\begin{array}{c}0.133 \\
(0.127)\end{array}$ & $\begin{array}{c}0.138 \\
(0.126)\end{array}$ & $\begin{array}{c}0.150 \\
(0.126)\end{array}$ \\
\hline Daytime temp. diff. (mean) & $\begin{array}{r}2.233^{z} \\
(0.085)\end{array}$ & $\begin{array}{r}2.224^{z} \\
(0.085)\end{array}$ & $\begin{array}{r}2.208^{z} \\
(0.085)\end{array}$ \\
\hline Percent shade & $\begin{array}{l}-0.159^{z} \\
(0.029)\end{array}$ & $\begin{array}{l}-0.163^{z} \\
(0.029)\end{array}$ & $\begin{array}{l}-0.164^{z} \\
(0.029)\end{array}$ \\
\hline Adj. $r^{2}:$ & 0.5932 & 0.5962 & 0.5964 \\
\hline F-statistic: & 170.3 & 160.1 & 140.4 \\
\hline $\mathrm{N}^{\mathrm{w}}:$ & 1510 & 1510 & 1510 \\
\hline \multicolumn{4}{|c|}{$\begin{array}{l}{ }^{\mathrm{z}} \text { significant at } 0.01 \text { level } \\
\mathrm{y} \text { significant at } 0.05 \text { level } \\
\mathrm{x} \text { significant at } 0.10 \text { level } \\
\text { w The total number of observations for five summer months during two years was } \\
1,510 \text {. A number of participants, out of } 160 \text {, reported only one year worth of } \\
\text { electricity data because they occupied the house only during the study year. Due } \\
\text { to differences in monthly observations between the two years, the total number of } \\
\text { observations is } 1,510 \text { not } 1,600 \text {. }\end{array}$} \\
\hline
\end{tabular}

As reported in Table $1 \mathrm{~b}$, the mean electricity usage across the sample was $58.50 \mathrm{kWh} /$ day. Each additional family member above

Table 2. Regression results (family size and composition). Dependent variable $=\mathrm{kWh} /$ day .

(C)2010 International Society of Arboriculture 
the sample mean (2.5) is associated with a $3.39 \mathrm{kWh} /$ day $(5.8 \%)$ increase in electricity usage. But not all family members contribute equally to electricity usage. Females use significantly more electricity than males, and children under the age of 12 use more electricity than family members over 12 . The latter finding will not surprise anyone who has had young children, who are apt to leave doors open, lights on, watch television, play video games, all of which imply a level of electricity consumption that is higher than that of adults.

For every additional $9.3 \mathrm{~m}^{2}$ of living space above the sample mean of $250.84 \mathrm{~m}^{2}$, an Auburn homeowner's electricity usage increases an estimated $1.3 \mathrm{kWh} /$ day (2.2\%). These findings indicate newer homes use significantly less energy than older homes. On average, a one-year-old home uses approximately $1.1 \mathrm{kWh} /$ day $(1.8 \%)$ less electricity, ceteris paribus, than an otherwise identical home that is 10 years older.

Using electricity to run one's water heater(s) increased electricity use by an estimated $4.5 \mathrm{kWh} /$ day $(7.8 \%)$. Having an extra freezer added roughly $2.5 \mathrm{kWh} /$ day $(4.2 \%)$ to electricity consumption. Each additional load of laundry run per week, over the sample mean of (5.53) increased electricity use by approximately 1.1 $\mathrm{kWh}$ /day (1.8\%). A swimming pool is an energy pig, where daily electricity consumption was $21 \mathrm{kWh}(35.9 \%)$ higher at homes with pools than at homes without pools. Every additional degree of difference between the mean daytime average temperature and the homeowner's desired thermostat setting raised electricity use in the 'typical' home by an estimated $2.2 \mathrm{kWh} /$ day $(3.8 \%)$.

Every $10 \%$ increase in the extent of shade coverage throughout the day reduced electricity use by approximately $1.6 \mathrm{kWh} /$ day $(2.7 \%)$. Controlling for other factors in the model, the study authors estimate that electricity use at a 'typical' house in the sample, characterized by mean shade coverage of $17.5 \%$ $(50 \%)$, was $4.7 \%(13.6 \%)$ lower than at a house with no shade.

Table 3 reports OLS regression results for models similar to those reported in Table 2, but with additional/alternative specifications of the shade parameters reflecting shade density and shade conditions at different times of the day. In terms of reducing electricity used for cooling, dense shade is better than light shade. At a 'typical' residence $(17.5 \%$ average shade coverage during the day) with dense shade, the electricity usage was an estimated $14.4 \%$ lower than a residence with no shade. Moreover, shade is especially important in the late afternoon when summertime temperatures peak. At a 'typical' residence with late afternoon shade, the electricity usage was an estimated $6 \%$ lower than a residence with no shade.

\section{CONCLUSION}

The electricity savings calculated from these models can be converted to monetary savings by multiplying the electricity savings in $\mathrm{kWh}$ per time period with the local power company's price per kWh. Auburn, Alabama is serviced by two electricity providers: Alabama Power Company and the Tallapoosa Electric Co-operative. Respective rates charged at the time of analysis were: USD $\$ 0.1152 / \mathrm{kWh}$ and $\$ 0.1229 / \mathrm{kWh}$.

For a 'typical' residence/family in this sample, the following monetary savings from shade during the summer months were estimated:

* Shade on the average house $(17.5 \%)$ reduced electricity usage by $4.8 \%$, as compared to a house with no shade, to a savings of approximately $\$ 10 /$ month.
Table 3. Regression results (shade conditions). Dependent variable $=\mathrm{kWh} /$ day.

\begin{tabular}{|c|c|c|c|}
\hline Explanatory Variables & Model 1 & Model 2 & Model 3 \\
\hline Intercept & $\begin{array}{l}-1.543 \\
(9.556)\end{array}$ & $\begin{array}{l}-3.504 \\
(9.575)\end{array}$ & $\begin{array}{r}-10.750 \\
(9.592)\end{array}$ \\
\hline Family size & $\begin{array}{r}3.594^{z} \\
(0.463)\end{array}$ & $\begin{array}{c}3.427^{2} \\
(0.467)\end{array}$ & $\begin{array}{r}3.620^{2} \\
(0.477)\end{array}$ \\
\hline Living area & $\begin{array}{c}0.013^{2} \\
(0.001)\end{array}$ & $\begin{array}{c}0.013^{z} \\
(0.001)\end{array}$ & $\begin{array}{c}0.013^{\mathrm{z}} \\
(0.001)\end{array}$ \\
\hline House age & $\begin{array}{c}0.057 \\
(0.042)\end{array}$ & $\begin{array}{r}0.101^{y} \\
(0.045)\end{array}$ & $\begin{array}{r}0.092^{y} \\
(0.047)\end{array}$ \\
\hline \# floors & $\begin{array}{c}1.416 \\
(1.042)\end{array}$ & $\begin{array}{c}1.793^{\mathrm{x}} \\
(1.051)\end{array}$ & $\begin{array}{r}1.828^{x} \\
(1.072)\end{array}$ \\
\hline Elec. Cooking & $\begin{array}{l}-0.912 \\
(1.271)\end{array}$ & $\begin{array}{l}-0.761 \\
(1.270)\end{array}$ & $\begin{array}{l}-0.609 \\
(1.291)\end{array}$ \\
\hline Elec. $\mathrm{H}_{2} \mathrm{O}$ heat & $\begin{array}{r}4.443^{z} \\
(0.969)\end{array}$ & $\begin{array}{r}4.456^{2} \\
(0.967)\end{array}$ & $\begin{array}{r}4.177^{2} \\
(0.981)\end{array}$ \\
\hline Window AC & $\begin{array}{c}4.530^{x} \\
(2.642)\end{array}$ & $\begin{array}{c}4.428^{x} \\
(2.638)\end{array}$ & $\begin{array}{r}4.648^{x} \\
(2.670)\end{array}$ \\
\hline Laundry loads/wk & $\begin{array}{c}1.009^{z} \\
(0.168)\end{array}$ & $\begin{array}{c}1.009^{\mathrm{z}} \\
(0.167)\end{array}$ & $\begin{array}{r}1.103^{z} \\
(0.168)\end{array}$ \\
\hline Second Freezer & $\begin{array}{c}2.519^{\mathrm{z}} \\
(0.947)\end{array}$ & $\begin{array}{c}2.602^{z} \\
(0.946)\end{array}$ & $\begin{array}{r}2.573^{2} \\
(0.957)\end{array}$ \\
\hline Swimming pool & $\begin{array}{c}22.223^{\mathrm{z}} \\
(1.719)\end{array}$ & $\begin{array}{c}21.539^{z} \\
(1.739)\end{array}$ & $\begin{array}{c}20.470^{2} \\
(1.765)\end{array}$ \\
\hline Average humidity & $\begin{array}{c}0.013 \\
(0.125)\end{array}$ & $\begin{array}{c}0.037 \\
(0.126)\end{array}$ & $\begin{array}{c}0.127 \\
(0.126)\end{array}$ \\
\hline Daytime temp. diff. (mean) & $\begin{array}{c}2.155^{2} \\
(0.083)\end{array}$ & $\begin{array}{c}2.192^{z} \\
(0.084)\end{array}$ & $\begin{array}{r}2.218^{z} \\
(0.085)\end{array}$ \\
\hline Percent shade & & $\begin{array}{l}-0.088^{y} \\
(0.036)\end{array}$ & \\
\hline Light shade & $\begin{array}{l}-0.254 \\
(1.431)\end{array}$ & $\begin{array}{c}0.43 \\
(1.457)\end{array}$ & \\
\hline Moderate shade & $\begin{array}{l}-0.507 \\
(1.289\end{array}$ & $\begin{array}{c}1.197 \\
(1.469)\end{array}$ & \\
\hline Heavy shade & $\begin{array}{l}-9.174^{z} \\
(1.356)\end{array}$ & $\begin{array}{l}-6.884^{z} \\
(1.655)\end{array}$ & \\
\hline Late a.m. shade percent & & & $\begin{array}{c}0.020 \\
(0.028)\end{array}$ \\
\hline Early p.m. shade percent & & & $\begin{array}{l}-0.005 \\
(0.047)\end{array}$ \\
\hline Late p.m. shade percent & & & $\begin{array}{l}-0.117^{2} \\
(0.022)\end{array}$ \\
\hline Adj. $r^{2}:$ & 0.6030 & 0.6043 & 0.5957 \\
\hline F-statistic: & 153.8 & 145.0 & 149.2 \\
\hline $\mathrm{N}:$ & 1510 & 1510 & 1510 \\
\hline
\end{tabular}

* A house with 50\% shade coverage during the day used $13.6 \%$ less electricity than an otherwise comparable house with no shade, to a savings of approximately $\$ 29 /$ month.

* At a 'typical' residence ( $17.5 \%$ average shade coverage during the day) with dense shade, the electricity usage was an estimated $14.4 \%$ lower than a residence with no shade, to a savings of approximately $\$ 31 /$ month.

* At a residence with $33 \%$ dense shade coverage during the day, the electricity usage was an estimated $16.7 \%$ lower than a residence with no shade, to a savings of approximately $\$ 33 /$ month.

* At a residence with $50 \%$ dense shade coverage during the day, the electricity usage was an estimated $19.3 \%$ lower than a residence with no shade, to a savings of approximately $\$ 42 /$ month. 
* At a 'typical' residence with late afternoon shade, the electricity usage was an estimated $6 \%$ lower than a residence with no shade, to a savings of approximately $\$ 13$ / month.

* At a residence with $50 \%$ shade coverage during the late afternoon, the electricity usage was an estimated $10 \%$ lower than a residence with no shade, to a savings of approximately $\$ 22 /$ month.

* At a residence with $75 \%$ shade coverage during the late afternoon, the electricity usage was an estimated $15 \%$ lower than a residence with no shade, to a savings of approximately $\$ 33 /$ month.

* At a residence with $100 \%$ shade coverage during the late afternoon, the electricity usage was an estimated $20 \%$ lower than a residence with no shade, to a savings of approximately $\$ 43 /$ month.

* At a 'typical' residence, with a thermostat setting of $76.35^{\circ} \mathrm{F}$ $\left(24.64^{\circ} \mathrm{C}\right)$ during the day, raising the thermostat setting by one degree Fahrenheit (1 degree Centigrade) reduced electricity use by $3.8 \%(6.84 \%)$, to a savings of approximately $\$ 8$ (\$15) per month. Obviously, these calculated monetary values/savings will change if/as rates change.

In addition to the natural air conditioning services they provide, trees affect the well-being of humans in various other ways. A list of the ways that trees beneficially affect mankind would include (but not be limited to): energy for heating/cooling, aesthetics, food source, habitat for wild animals that humans value, forage for domesticated animals, medicines, construction materials, and natural filtration services that improve the quality and flow rates of surface waters. For the most part, the services provided by trees are not priced, which presents a very particular problem from an economics/management perspective. Typically, we use prices as a benchmark for assigning values to things. In the absence of prices, there may be a tendency to overlook or ignore the values contributed to our lives by trees. In turn, this increases the likelihood that trees will be cut down or managed in ways that contribute less-than-optimally to human welfare and/or ecological sustainability. One of the scientific challenges we face, then, is to assign values to the services provided by trees as a precondition for more effective management.

Acknowledgments. This research was supported by grant \#07-DG11420004-027 provided by the National Urban and Community Forestry Advisory Council (NUCFAC) and by a McIntire-Stennis grant provided to the second author and administered through the SFWS at Auburn University. Our research has benefited from suggestions received from two anonymous reviewers and an associate editor, as well as comments made during seminar presentations at the School of Forestry at the University of Melbourne, CSIRO - Atherton (Australia), the Department of Economics at the University of Adelaide, and the Institute of Forestry, Tribhuvan University, Pokhara, Nepal. However, responsibility for the findings presented rests solely with the authors.

\section{LITERATURE CITED}

Akbari, H., S. Davis, J. Huang, S. Dorsano, and S. Winnett. 1992. Cooling our communities: A guidebook on tree planting and light-colored surfacing. Lawrence Berkeley Laboratory Report LBL-31587. US Environmental Protection Agency, Office of Policy Analysis, Climate Change Division, Washington, D.C. 217 pp.

Akbari, H., D.M. Kurn, S.E. Bretz, and J.W. Hanford. 1997. Peak power and cooling energy savings of shade trees. Energy and Buildings 25:139-148.

Carver, A.D., D.R. Unger, and C.L. Parks. 2004. Modeling Energy Savings from Urban Shade Trees: An Assessment of the CITYgreen ${ }^{\circledR}$ Energy Conservation Module. Environmental Management 34:650-655.

Clark, K.E., and D. Berry. 1995. House characteristics and the effectiveness of energy conservation measures. Journal of the American Planning Association 61:386.

Forbes Magazine. 2008. America's Fastest-Growing Metros. <http:// www.forbes.com/business/2008/01/30/economy-cities-alabama-bizcx-bw_0130econcities.html> Accessed 9/08.

Huang, Y.J., H. Akbari, H. Taha, and A.H. Rosenfeld. 1987. The Potential of Vegetation in Reducing Summer Cooling Loads in Residential Buildings. Journal of Applied Meteorology 26:1103-1116.

Jensen, R.R., J.R. Boulton, and B.T. Harper. 2003. The Relationship Between Urban Leaf Area and Household Energy Usage in Terre Haute, Indiana, U.S. Journal of Arboriculture 29:226-230.

Laverne, R.J., and G.M.D. Lewis. 1996. The Effect of Vegetation on Residential Energy Use in Ann Arbor, Michigan. Journal of Arboriculture 22:234-243.

Lechner, Norbert. 1991. Heating, Cooling, Lighting: Design Methods for Architects. John Wiley \& Sons, New York, NY. 620 pp.

McPherson, E.G., D. Nowak, G, Heisler, S. Grimmond, C. Souch, R. Grant, and R. Rowntree. 1997. Quantifying urban forest structure, function, and value: the Chicago Urban Forest Climate Project. Urban Ecosystems 1:49-61.

McPherson, G., and J.R. Simpson. 1995. Shade trees as a demand-side resource. Home Energy Magazine (Mar-Apr) 12:11-17.

Parker, J.H. 1983. Landscaping to reduce the energy used in cooling buildings. Journal of Forestry 81:82-104.

Rudie, R.J., and R.S. Dewers. 1984. Effects of tree shade on home cooling requirements. Journal of Arboriculture 10:320-322.

Simpson, J.R., and E.G. McPherson. 1996. Potential of tree shade for reducing residential energy use in California. Journal of Arboriculture 22:10-18. 
Ram Pandit (corresponding author) Assistant Professor

School of Agricultural and Resource Economics University of Western Australia

Crawley WA 6009

Australia

ram.pandit@uwa.edu.au

David N. Laband

Professor

Economics and Policy

School of Forestry and Wildlife Sciences

Auburn University

602 Duncan Drive

Auburn, AL 36849-5418, U.S.
Résumé. Les arbres produisent de l'ombre sur les maisons et les édifices, permettant ainsi de diminuer les températures à l'intérieur et de ce fait la demande en énergie pour climatiser ces bâtiments durant les périodes chaudes de l'année. Dérivé à partir d'un large échantillon de résidences à Auburn en Alabama (U.S.A.), un modèle statistique a été développé pour produire des estimés spécifiques d'économie d'électricité générée par les arbres produisant de l'ombre dans un environnement suburbain. Ce modèle empirique lie la consommation énergétique résidentielle avec des caractéristiques hédoniques de structure, de types de comportement des occupants, ainsi que d'étendue et de densité d'ombrage projetés sur les structures à différents moments de la journée.

Zusammenfassung. Bäume werfen Schatten auf Häuser und Gebäude, verringern die Innentemperaturen und reduzierten dadurch die Nachfrage an Energie, um diese Häuser in heißen Jahreszeiten herunterzukühlen. Basierend auf einer großen Erhebung in Auburn/Alabama U.S. wurde ein statistisches Modell entwickelt zur spezifischen Abschätzung der Elektrizitätseinsparung durch von Bäumen gespendeten Schatten in einer suburbanen Gegend. Dieses empirische Modell verbindet Energieverbrauch von Haushalten mit den hedonischen Merkmalen der Baustrukturen, Eigenschaften/Verhalten der Teilnehmer und das Ausmaß und Dichte von Schatten auf die Bauwerke zu bestimmten Tageszeiten.

Resumen. Los árboles proveen sombra a casas y edificios: disminuyendo las temperaturas interiores y de esta manera reduciendo la demanda de energía para enfriar esas edificaciones durante las épocas de calor en un año. A partir de una muestra de residencias en Auburn, Alabama U.S., se desarrolló un modelo estadístico para producir estimaciones específicas de los ahorros de electricidad generados por los árboles de sombra en un ambiente suburbano. Este modelo empírico liga los consumos de energía residencial a las características de las estructuras, comportamientos de los ocupantes, y de allí a la densidad de la sombra en las estructuras a diferentes momentos del día. 